\title{
A Century of Training in Preventive Medicine in Latvia
}

\author{
Jānis Indulis Dundurs* \\ Department of Occupational and Environmental Medicine, Riga Stradinš̌ university, Latvia, Europe
}

*Corresponding author: Jānis Indulis Dundurs, Department of Occupational and Environmental Medicine, Riga Stradinš university, Latvia, Europe.

Received Date: February 23, 2020

Published Date:February 27, 2020

\section{Opinion}

This year we will mark the centenary since the beginning of studies in higher education in Latvia. On February 2, 1920, the first lecture on anatomy was read. After a year, the Hygiene Institute was established at the Faculty of Medicine of the Higher School of Latvia and the Department of Hygiene was founded on August 15 , which can be considered as the predecessor of the present RSU Department of Occupational and Environmental Medicine. Our goal was to collect and track the changes that have taken place in the training of new medical and healthcare professionals in hygiene in our department for almost a hundred years.

The first Head of the Department was German professor Ernest Friedrich Alexander Fermann, who had worked in the cities of the Russian Empire for many years. During the years of the pre-war independence of Latvia, student training in the Department was carried out according to the research and findings of the time that had been developed in 19th century by most notable German and Russian hygienists.

From 1928, lectures in the Department were also given of science related to hygiene-microbiology, general and special epidemiology. During World War II, the Head of the Department was Professor Victor Mīlenbahs, the youngest colleague of Professor E Fermann.

In the first years of post-war Soviet occupation, several months ago, the head of the Department was Professor Janis Maizite, and from 1947 the chair was headed by hygienists sent from the Russian Federal Soviet Republic, first by Assistent Professor Alexander Anisimov and later by Assistent Professor Mikhail Garbarenko. The training took place in the framework of the unified programs developed in the Soviet Union, which included courses in Health Care Organization and Military Hygiene.

Since 1962, Professor Zinaida Lindberg has taken over the Chair of the Department, which first provided quality training for the students of the Latvian flow in their native language. However, until the restoration of independence of the Republic of Latvia, only minor changes were made to the study programs:

- $\quad$ interrupted course in Military hygiene.

- new Department of the same name has been created for the presentation of the course of the Health Care Organization.

- $\quad$ textbooks written by the Department's lecturers outline only the theoretical and practical aspects of the various Hygiene sectors recognized by the Soviet Union

With the restoration of our country's independence, the Hygiene Department underwent significant changes.

1990 Hygiene department began to drive by professor of occupational specialty M. Eglīte and training also included occupational courses, but the Department of the name until 1993 was-Hygiene and Occupational Diseases Department.

Scientific and technical development, by extending the ecological range of environmental factors, has led to a loss of balance between the biological characteristics of man and his ability to adapt to the new technogenic factors of the environment in a timely manner. Due to global environmental pollution, the mutual, complementary and influential role of hygiene and human ecology has grown rapidly.

Both human ecology and hygiene have a common basis, a common goal in addressing the global crisis of the ecosystem. The science sector - human ecology - gained a greater and deeper meaning in training. From 1993 to 1996, the Department was called the Department of Human Ecology and Occupational Diseases.

In the medical education system, hygiene and human ecology were complementary subjects within a short period of time when 
there was no special study program and methodological study material.

Since 1997, the Department has been named the Department of Occupational and Environmental Medicine.

Environmental and Occupational Health and Medicine is the main subject of the medical preventive course, emphasizing the specifics of the students' future work environment.

Environmental health training is based on the socio-hygienic and medical biological regularities in the system environmenthuman - society. The holistic view is decisive - health is equally affected by lifestyle and living conditions.

In order to provide high quality training, several lecturers at the department completed special courses in occupational and environmental medicine at Uppsala University in Sweden. Completely new study programs were developed for all faculties of medical direction of Riga Stradinš University.

Department lecturers with a lot of research and practical work experience led studies of Medicine, Nursing, Pharmacy, Rehabilitation, Dentistry and Public Health faculties. Training is provided with teaching aids written by the lecturers of the department - textbooks, booklets, video collections, modern equipment for practical classes (luxometers, hot wire anemometers, infrared thermometers, conductometers, noise level meters, ultraviolet intensity meters, electromagnetic field meters, infrared spectrometer, etc.).

Teachers have written several books and chapters on environmental and work environment risk factors, hazards, identification, recognition, anticipation, measurement, evaluation, management and control. Professor M Eglīte's book on occupational medicine has been published twice.
Ten years ago, students received a new, extensive textbook on environmental health, in which separate chapters were written by our lecturers and specialists in teaching. And now the team is committed to updating this learning tool with the latest insights and research on environmental pollution problems.

The lecturers of the Department constantly improve their knowledge by participating in various seminars, courses, conferences all in Latvia and abroad. The fact that the chair of the department's management is in safe hands is evidenced by the award of the State Star of Three Stars to the Head of the department, Professor M Eglīte.

\section{Conclusion}

In the past twenty years, significant improvements have been made in hygiene training on the way to developing a European single higher education system and quality assurance. The Department of Hygiene was renamed, and the main subject has become environmental and occupational health. The principle of teaching environmental and occupational health is to find out the relationship between human and medical biological and social hygiene factors. Research is based on theoretical part and practical work that allows students to acquire knowledge and skills for future work

\section{Acknowledgment}

None.

\section{Conflict of Interest}

No conflict of interest 